\title{
IN VITRO SEALING ABILITY OF WHITE AND GRAY MINERAL TRIOXIDE AGGREGATE (MTA) AND WHITE PORTLAND CEMENT USED AS APICAL PLUGS
}

\author{
Patrícia Zanatta Aranha CONEGLIAN ${ }^{1}$, Fernando Accorsi OROSCO ${ }^{1}$, Clóvis Monteiro BRAMANTE ${ }^{2}$, \\ Ivaldo Gomes de MORAES ${ }^{3}$, Roberto Brandão GARCIA ${ }^{3}$, Norberti BERNARDINELI ${ }^{3}$
}

1- Master's degree student in Endodontics, Bauru School of Dentistry, University of São Paulo, Bauru, SP, Brazil.

2- Full Professor of Endodontics, Bauru School of Dentistry, University of São Paulo, Bauru, SP, Brazil.

3- Associate Professor of Endodontics, Bauru School of Dentistry, University of São Paulo, Bauru, SP, Brazil.

Corresponding address: Patrícia Z. A. Coneglian - Departamento de Endodontia - Faculdade Odontologia de Bauru, Universidade de São Paulo

Alameda Octávio Pinheiro Brisolla, 9-75, Vila Universitária - 17012-901. C.P.: 73 Bauru, SP, Brasil.

Phone: 5514 3235-8344 - Fax: 5514 3224-2788 - e-mail: pzaconeglian@terra.com.br

Received: September 29, 2006 - Modification: March 30, 2007 - Accepted: May 11, 2007

\begin{abstract}
$\Gamma_{\text {his }}$ This study evaluated the sealing ability of apical plugs made of white and gray MTA-Angelus ${ }^{\circledR}$ and white Portland cement placed via the root canal and having different thicknesses $(2,5$ and $7 \mathrm{~mm}$ ). Ninety extracted human single-rooted teeth were instrumented using a size $40 \mathrm{~K}$-file to standardize the foraminal opening by the stepback technique. The teeth were assigned to 3 groups ( $n=30$ ), according to the material used for fabrication of the apical plugs: A = gray MTA; $B=$ white MTA; $C=$ white Portland cement. The groups were subdivided into groups of 10 teeth each according to the apical plug thickness (2, 5 and 7 $\mathrm{mm}$ ). Marginal apical dye leakage was assessed using $0.2 \%$ Rhodamine B solution in which the specimens were immersed for 72 hours at $37^{\circ} \mathrm{C}$. The roots were sectioned longitudinally in a buccolingual direction for apical plug exposure, and digital photographs were taken and analyzed by Image Tool image-analysis software. Data were analyzed statistically by KruskalWallis and Dunn's tests. Significance level was set at 5\%. The least percent leakage was observed for 5- and 7-mm-thick plugs $(p<0.05)$. No significant difference $(p>0.05)$ was found between gray MTA and white Portland cement. Among the three materials analyzed, white MTA presented the highest marginal leakage $(\mathrm{p}<0.05)$. The findings of the present study showed that gray MTA and Portland cement had better sealing ability than white MTA when used as apical plugs. Dye leakage was smaller for 5- and 7-mm-thick plugs compared to 2-mm-thick plugs.
\end{abstract}

Uniterms: Apical plug; Leakage; Mineral trioxide aggregate; Portland cement.

\section{INTRODUCTION}

In some clinical situations, such as root canal overinstrumentation, apical resorption and teeth with open apices, there may be extrusion of the filling material, either gutta-percha, root canal sealer or both, due to the difficulty or impossibility to lock the master gutta-percha cone. In these situations, fabrication of an apical plug with calcium hydroxide and, more recently, with mineral trioxide aggregate (MTA) has been suggested ${ }^{2,4,13,21,25,26}$.

MTA was introduced in the early 1990's as an experimental material developed by Dr. Mahmoud Torabinejad at Loma Linda University, USA. This material was originally indicated as a retrograde filling material for use in endodontic surgery and cases of intraradicular and furcal perforations ${ }^{18}$. Since then, it has been used in different clinical situations, such as communicating internal and external resorptions, as capping material in mechanically exposed pulps, as intracoronal barrier during internal bleaching of endodontically treated teeth, and as apical plug in case of difficulty to lock the master gutta-percha cone $\mathrm{e}^{4}$. These indications of MTA are related to the possibility of use in moist environments, as in most aforementioned indications, and mainly to its biocompatibility ${ }^{4,26}$.

The sealing ability of MTA apical plug and its thickness have been investigated by several authors ${ }^{2,13,16,17,20,21,26}$. Four-millimeter-thick plugs have been shown to be the most efficient with respect to root canal sealing ability and resistance to displacement ${ }^{13,20,21,26}$. All of these studies have sought an alternative to MTA apical plug as well as its most appropriate thickness.

Wucherpfennig and Green ${ }^{27}$ (1999) have called the 
attention to the fact that MTA and Portland cement were similar materials. Other studies were conducted and confirmed this similarity by means of microbiological, chemical, physical and biological behavior tests 1,5,8,10,11,15,23 $^{\text {. }}$

The purpose of this study was to evaluate the sealing ability of apical plugs made of white and gray MTA-Angelus ${ }^{\circledR}$ (Angelus Soluções em Odontologia, Londrina, PR, Brazil) and white Portland cement (Votorantim Cimentos, Votorantim, São Paulo, SP, Brazil) placed via the root canal and having different thicknesses (2, 5 and $7 \mathrm{~mm}$ ).

\section{MATERIALAND METHODS}

This study was approved by the Institutional Review Board of the Dental School of Bauru, University of São Paulo, Brazil. Ninety extracted human single-rooted teeth with intact roots and completely formed apices were used. The teeth were obtained from the files of the Department of Endodontics of the Dental School of Bauru and were kept in $10 \%$ aqueous formalin solution.

The dental crowns were sectioned at the cementoenamel junction with a low-speed diamond saw (KG Sorensen, São Paulo, SP, Brazil) under continuous water spray to obtain access to the root canal. The root canal length was determined by inserting a size $15 \mathrm{~K}$-file (Dentsply-Maillefer Instruments SA, Ballaigues, Switzerland) into the canal until its tip reached the apical foramen. The working length was established by subtracting $1 \mathrm{~mm}$ from this measurement. The stepback technique was employed and the root canal was flared using a size $60 \mathrm{~K}$-file to the working length. Instrumentation was aided by irrigation with $1 \mathrm{~mL}$ of $1 \%$ sodium hypochlorite solution (Biodinâmica Química e Farmacêutica Ltda, Ibiporã, PR, Brazil) alternated with the sequence of instruments, followed by a final flushing with 1 $\mathrm{mL}$ of sterile water.

The teeth were assigned to 3 groups $(n=30)$, according to the material used for fabrication of the apical plugs: Group $\mathrm{A}=$ placement of gray MTA-Angelus ${ }^{\circledR}$ plugs; Group B = placement of white MTA-Angelus ${ }^{\circledR}$ plugs; Group $\mathrm{C}=$ placement of white Portland cement plugs. The groups were further subdivided into groups of 10 teeth each, according to the thickness of the apical plugs, namely 2, 5 and $7 \mathrm{~mm}$ (Table 1).

Before standardization of the foraminal opening, the roots were made impermeable by application of a layer of epoxy adhesive (Araldite-Ciba-Geigy S.A., Taboão da Serra,
SP, Brazil), followed by two coats of nail polish (Cosbra Cosmeticos Ltda., São Paulo, SP, Brazil). The foramen diameter was standardized by inserting the $40 \mathrm{~K}$-file $1 \mathrm{~mm}$ beyond the apical foramen, so that only the apical opening would not be impermeable.

For fabrication of the apical plugs, the tested materials were applied with a size 4 Lentulo spiral (Dentsply-Maillefer Instruments SA, Ballaigues, Switzerland) at the apical end of the root, trying to fill it completely. The material was condensed with the tip of a size $40 \mathrm{~K}$-file involved in cotton for achievement of the plug ${ }^{19}$. Next, using a size $40 \mathrm{~K}$-file with a rubber stop positioned 2, 5 and $7 \mathrm{~mm}$ shorter than the root canal length, the excess material was removed for fabrication of 2-, 5- and 7-mm-thick apical plugs, respectively. Finally, the root canal walls were cleaned with the tip of an instrument wrapped in moist cotton.

The materials were allowed complete setting (nearly 3 hours). Then, the canal entrances were sealed with epoxy adhesive and nail polish, and the roots were immersed in 0.2 \% Rhodamine B solution (Labsynth Produtos para Laboratórios Ltda, Diadema, SP, Brazil) at pH 7.0 for 72 hours at $37^{\circ} \mathrm{C}$. After this period, the roots were removed from the dye, washed in running water for 24 hours, had the impermeable coating scraped away and were washed for additional 12 hours.

The roots were then sectioned longitudinally in a buccolingual direction for exposure of the apical plugs, photographed with a digital camera (Canon EOS Rebel 300 D) and analyzed by Image Tool software (University of Texas Health Science Center, San Antonio, TX, USA). Data were analyzed statistically by Kruskal-Wallis and Dunn's tests. Significance level was set at 5\%.

\section{RESULTS}

Table 2 shows the percent marginal leakage for the different materials for each plug thickness. Tables 3, 4 and 5 show the results of the Kruskal-Wallis statistical test for comparison among groups A (MTA-Angelus ${ }^{\circledR}$ gray), B (MTA-Angelus ${ }^{\circledR}$ white) and C (white Portland cement) with respect to the plug thicknesses (2, 5 and $7 \mathrm{~mm})$.

A statistically significant difference $(p<0.05)$ was observed between groups A and B as to the leakage in 2mm-thick plugs, with better results for group A (Table 3). Materials did not show statistically significant difference ( $>>0.05$ ) when groups with 5-mm-thick plugs were compared

TABLE 1- Distribution of teeth in the groups with respect to the plug thickness and material

\section{Groups Material}

Plug Thickness (mm)

5

7

$\begin{array}{lll}10 & 10 & 10 \\ 10 & 10 & 10 \\ 10 & 10 & 10\end{array}$


to each other (Table 4). Regarding the 7-mm-thick plugs, there was statistically significant difference $(\mathrm{p}<0.05)$ between groups $\mathrm{A}$ and $\mathrm{B}$ and between groups $\mathrm{B}$ and $\mathrm{C}$, with worst results for group B in both comparisons (Table 5).

In Figure 1 shows the graphic presentation of percent marginal leakage ( $0.2 \%$ Rhodamine $B)$ in the root canals, regarding the tested materials and plug thicknesses. It is possible to verify that 2-mm-thick plugs yielded the least satisfactory results in all groups, whereas the 7-mm-thick plugs yielded the best results for groups A and C, yet not for group $B$, in which the 5 -mm-plugs had the best results as to dye leakage.

\section{DISCUSSION}

This study investigated the sealing ability of gray MTA, white MTA and white Portland cement used for fabrication of apical plugs, given that this procedure is often required in the clinical practice ${ }^{12,14,19}$, mainly in cases where appropriate adaptation of the master gutta-percha cone is difficult. Torabinejad and Chivian ${ }^{25}$ (1999) pointed out that the goal of an apical plug is to induce hard tissue formation, in order to prevent filling material extrusion in teeth with open apices.

The use of methylene blue in marginal sealing studies has been questioned, due to its incompatibility with alkaline substances, which may induce discoloration of the dye. Calcium oxide is one of the components found in MTA. When calcium oxide is mixed with water, it results in the formation of calcium hydroxide, with a subsequent increase in $\mathrm{pH}$, as previously demonstrated by Duarte, et al. ${ }^{9}$ (2003). Thus, discoloration of the surfaces stained by methylene blue may occur. Therefore, Rhodamine B dye solution is more appropriate for evaluating the sealing ability of MTA $^{22,24}$.

In the present study, 5- and 7-mm-thick plugs were more efficient for apical sealing than 2-mm-thick plugs, regardless of the material utilized (Table 1 and Figure 1), which is in agreement with the findings of previous ${ }^{2,13,21,26}$. In group B (white MTA), the 5-mm-thick plugs had better performance than the 2- and 7-mm-thick plugs, yet without statistically significant difference. With regard to tested materials, no statistical difference was expected among them because the chemical components of MTA and Portland cement are the same, except for bismuth oxide, which provides radiopacity to $\mathrm{MTA}^{8,10,11}$.

Camilleri, et al. ${ }^{7}$ (2005) evaluated the chemical constitution
TABLE 3- Comparison among groups A (gray MTA), B (white MTA) and C (white Portland cement) for 2-mm-thick apical plugs

\begin{tabular}{lcc}
$\begin{array}{l}\text { Stat } \\
\text { Nonpar } \\
\text { Stats }\end{array}$ & $\begin{array}{r}\text { Kruskal-Wallis ANOVA by Ranks } \\
\text { (dados_infil.sta) }\end{array}$ \\
& $\begin{array}{r}\text { Independent (grouping) variable: Group } \\
\text { Kruskal-Wallis test: } \mathrm{H}(2 ; \mathrm{N}=30)=6.609514 \\
\text { Dunn test: } \mathrm{p}=0.0367\end{array}$ \\
\hline Depend.: & Valid (N) & Sum of Ranks \\
INFILT_\% & & 108.0000 \\
A & 10 & 208.0000 \\
B & 10 & 149.0000 \\
C & 10 & \\
\hline
\end{tabular}

TABLE 4- Comparison among groups A (gray MTA), B (white MTA) and C (white Portland cement) for 5-mm-thick apical plugs

\begin{tabular}{lcc}
\hline $\begin{array}{l}\text { Stat } \\
\text { Nonpar } \\
\text { Stats }\end{array}$ & $\begin{array}{r}\text { Kruskal-Wallis ANOVA by Ranks } \\
\text { (dados_infil.sta) }\end{array}$ \\
& $\begin{array}{r}\text { Independent (grouping) variable: Group } \\
\text { Kruskal-Wallis test: } \mathrm{H}(2 ; \mathrm{N}=30)=0.0393611 \\
\text { Dunn test: } \mathrm{p}=0.9805\end{array}$ \\
\hline Depend.: & Valid (N) & Sum of Ranks \\
INFILT_\% & & 150.0000 \\
A & 10 & 157.5000 \\
B & 10 & 150.5000 \\
C & 10 & \\
\hline
\end{tabular}

TABLE 5- Comparison among groups A (gray MTA), B (white MTA) and C (White Portland cement) for 7-mm-thick apical plugs

\begin{tabular}{lc}
\hline Stat & Kruskal-Wallis ANOVA by Ranks \\
Nonpar & (dados_infil.sta) \\
Stats & Independent (grouping) variable: Group \\
& Kruskal-Wallis test: $\mathrm{H}(2 ; \mathrm{N}=30)=15.08129$ \\
& Dunn test: $\mathrm{p}=0.0005$ \\
\hline
\end{tabular}

\begin{tabular}{lcc}
\hline Depend.: & Valid $(\mathrm{N})$ & Sum of Ranks \\
INFILT_\% & & \\
A & 10 & 117.0000 \\
B & 10 & 243.0000 \\
C & 10 & 105.0000 \\
\hline
\end{tabular}

TABLE 2- Percent dye leakage for the tested materials and plug thicknesses

\section{Material}

Plug Thickness (mm)

2
68.76

69.14

66.80
7

44.07

96.85

91.85
71.51

42.44 
and biocompatibility of white and gray Portland cement, white and gray MTA, Portland cement clinker without calcium sulfate and Portland cement clinker without calcium sulfate with addition of bismuth oxide. They concluded that the chemical composition of the tested materials is similar, primarily containing tricalcium silicate and dicalcium silicate. The white cements differ from the gray cements by the small quantity of iron oxide (FeO), while MTA differs from Portland cement due to the presence of bismuth oxide. There was no difference between white and gray MTA, and the addition of bismuth oxide did not interfere with the biocompatibility of cements. In the present study, white MTA showed poorer results than gray MTA and white Portland cement for all tested plug thicknesses (Table 1).

Asgary, et al. ${ }^{3}$ (2005) observed significant differences between gray and white MTA, especially in the contents of aluminum trioxide $\left(\mathrm{Al}_{2} \mathrm{O}_{3}\right)$, magnesium oxide $(\mathrm{MgO})$ and iron oxide (FeO). However, these differences are not enough to explain the results of the present study, in which gray MTA showed better results than white MTA as to dye leakage. Matt, et al. ${ }^{21}$ (2004) observed similar results in their study, where apical plugs made with gray MTA were more efficient than those made with white MTA.

As to the fabrication of apical plugs, Torabinejad and Chivian $^{25}$ (1999) recommended carrying the MTA with a large amalgam carrier to the root canal and then condensing the material to the apical end of the root with pluggers or paper points. Sometimes, this procedure is difficult due to the root canal diameter and anatomy. In the present study, MTA and Portland cement were carried to the root canal with a size 4 Lentulo spiral, according to the technique proposed by Bramante, et al. ${ }^{6}$ (2004). The Lentulo spiral is used to carry the MTA in paste consistence more easily to the root canal end in a fast and correct manner. Another important factor is

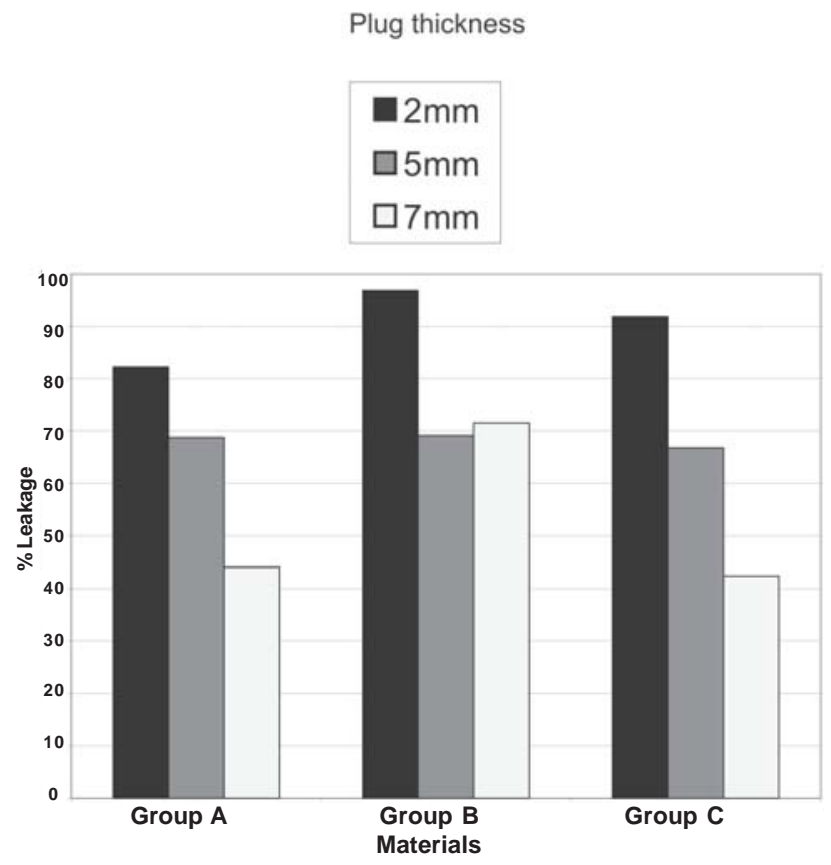

FIGURE 1- Marginal leakage (\%) of $0.2 \%$ Rhodamine B in root canals according to the materials utilized and plug thickness material condensation at the end of the root canal because the apical plug should resist the filling material. This condensation is more effective when performed with a Kfile compatible with the root canal diameter and with the tip wrapped in a cotton mesh. Cleaning of the root canal walls and removal of excess material must be performed with the same K-file wrapped in moist cotton in sterile saline, not to interfere with the proper root canal filling.

\section{CONCLUSION}

The findings of the present study showed that gray MTA and Portland cement had better sealing ability than white MTA when used as apical plugs. Dye leakage was smaller for 5- and 7-mm-thick plugs compared to 2-mm-thick plugs.

\section{REFERENCES}

1- Abdullah D, Ford TR, Papaioannou S, Nicholson J, McDonald F. An evaluation of accelerated Portland cement as a restorative material. Biomaterials. 2002;23(19):4001-10.

2- Al-Kahtani A, Shostad S, Schifferle R, Bhambhani S. In vitro evaluation of microleakage of an orthograde apical plug of mineral trioxide aggregate in permanent teeth with simulated immature apices. J Endod. 2005;31(2):117-9.

3- Asgary S, Parirokh M, Eghhal MJ, Brink F. Chemical differences between white and gray mineral trioxide aggregate. J Endod. 2005;31(2):101-3.

4- Bernabé PFE, Holland R. MTA e cimento Portland: considerações sobre as propriedades físicas, químicas e biológicas. In: Cardoso RJA, Machado MEL. Odontologia arte e conhecimento. São Paulo: Artes Médicas; 2003. p. 225-64.

5- Bortoluzzi EA, Broon NJ, Bramante CM. Avaliação da capacidade seladora do MTA e cimento Portland com ou sem cloreto de cálcio em obturações retrogrades [resumo Pc082]. Braz Oral Res. 2004;18(Suppl 1):213. Apresentado na 21 ${ }^{\text {a }}$ Reunião Anual da Sociedade Brasileira de Pesquisa Odontológica; 2004; Águas de Lindóia, SP.

6- Bramante CM, Bortoluzzi EA, Broon NJ. Agregado trióxido mineral (MTA) como plug apical para la obturación de conductos radiculares: descripción de la técnica y caso clínico. Endodoncia. 2004; 22(3):15561.

7- Camilleri J, Montesin FE, Di Silvio L, Pitt Ford TR. The chemical constitution and biocompatibility of accelerated Portland cement for endodontic use. Int Endod J. 2005;38(11):834-42.

8- Deal BF, Wenckus CS, Johnson BR, Fayad MI. Chemical and physical properties of MTA, Portland cement, and a new experimental material, fast-set MTA [abstract]. J Endod. 2002;28:252.

9- Duarte MAH, Demarchi AC, Yamashita JC, Kuga MC, Fraga SC. $\mathrm{pH}$ and calcium ion release of 2 root-end filling materials. Oral Surg Oral Med Oral Pathol Oral Radiol Endod. 2003;95(3):345-7.

10- Estrela C, Bammann LL, Estrela CRA, Silva RS, Pécora JD. Antimicrobial and chemical study of MTA, Portland cement, calcium hydroxide paste, Sealapex and Dycal. Braz Dent J. 2000;11(1):3-9.

11- Funteas UR, Wallace JA, Fochtman FW. A comparative analysis of Mineral Trioxide Aggregate and Portland cement. Aust Endod J. 2003;29(1):43-4. 
12- Giuliani V, Baccetti T, Pace R, Pagavino G. The use of MTA in teeth with necrotic pulps and open apices. Dent Traumatol. 2002;18(4):217-21.

13- Hachmeister DR, Schindler WG, Walker WA, Thomas DD. The sealing ability and retention characteristics of mineral trioxide aggregate in a model of apexification. J Endod. 2002;28(5):386-90.

14- Hayashi M, Shimizu A, Ebisu S. MTA for obturation of mandibular central incisors with open apices: case report. J Endod. 2004;30(2):120-2.

15- Holland R, de Souza V, Nery MJ, Faraco IM Junior, Bernabe PF, Otoboni JA Filho, et al. Reaction of rat connective tissue to implanted dentin tube filled with mineral trioxide aggregate, Portland cement or calcium hydroxide. Braz Dent J. 2001;12(1):3-8.

16- Kwak KI, Park DS, Oh TS. The effect of obturation timing and thickness of mineral trioxide aggregate matrix on sealing ability [abstract]. J Endod. 2000;26:557.

17- Lamb EL, Loushine RJ, Weller RN, Kimbrough WF, Pashley DH. Effect of root resection on the apical sealing ability of mineral trioxide aggregate. Oral Surg Oral Med Oral Pathol Oral Radiol Endod. 2003;95(6):732-5.

18- Lee SJ, Monsef M, Torabinejad M. Sealing ability of a mineral trioxide aggregate for repair of lateral root perforations. J Endod. 1993;19(12): 541-4.

19- Levenstein H. Obturating teeth with wide open apices using mineral trioxide aggregate: a case report. SADJ. 2002;57(7):270-3.

20- Mah T, Basrani B, Santos J, Pascon EA, Tjäderhane L, Yared G, et al. Periapical inflammation affecting coronally-inoculated dog teeth with root fillings augmented by white MTA orifice plugs. J Endod. 2003;29(7):442-6.

21 - Matt GD, Thorpe JR, Strother JM, McClanahan SB. Comparative study of white and gray mineral trioxide aggregate (MTA) simulating a one-or-two-step apical barrier technique. J Endod. 2004;30(12):876-

22- Moraes IG, Moraes FG, Mori GG, Gonçalves SB. Influence of calcium hydroxide on dyes for dentin labeling, analyzed by means of a new methodology. J Appl Oral Sci. 2005;13(3):218-21.

23- Silva RF, Emílio de Souza R, Galhardo R, Cruz-Filho AM, SouzaNeto MD. Estudo das propriedades de estabilidade dimensional, solubilidade e desintegração dos cimentos MTA e dois tipos de cimento Portland [resumo]. Braz Oral Res. 2002;16 Suppl 1:145.

24- Tanomaru M Filho, Figueiredo FA, Tanomaru JMG. Effect of different dye solutions on the evaluation of the sealing ability of mineral trioxide aggregate. Braz Oral Res. 2005;19(2):119-22.

25- Torabinejad M, Chivian N. Clinical applications of mineral trioxide aggregate. J Endod. 1999;25(3):197-205.

26- Valois CRA, Costa ED Jr. Influence of the thickness of mineral trioxide aggregate on sealing ability of root-end filling in vitro. Oral Surg Oral Med Oral Pathol Oral Radiol Endod. 2004;97(1):108-11.

27- Wucherpfennig AL, Green DB. Mineral trioxide aggregate vs Portland cement: two biocompatible filling materials [abstract]. J Endod. 1999;25:308. 